\title{
著者からの返事
}

\author{
編集者への手紙（日輸会誌42（5）：231－232，1996.） \\ に対するコメント
}

\section{Comment on the letter to the editor}

\author{
佐 藤 博 行 \\ 福岡県赤十字血液センター
}

Key words : Human Parvovirus B19, Receptor-mediated hemagglutination, PCR, Donor screening

“ヒトパルボウイルス B19とその感染症につい て”的に示した如く，供血者を含む一般正常人に於 けるヒトパルボウイルスの感染様式は急性感染症 の形をとり，3〜 5 日間のウイルス血症期 ( I 期) に引き続いて $2 \sim 3$ カ月に及ぶ抗原抗体複合物血 症の時期（II期）が存在する. 臨床症状としては 筋肉痛, 悪寒, 発熱が見られる時が I 期に, 紅斑, 関節痛, 関節炎が見られる時期がII期に相当する. Receptor-mediated hemagglutination 法 (RHA) は I 期にある血液を, PCR は I 期及びII 期の血液 を検出する，時間的には，II期は I 期の約 20 倍の 長さがあり，I. 期，II期の区別なく献血が行われ るならば，RHA (-) PCR (+) の血液は RHA $(+) \mathrm{PCR}(+)$ の約20倍の頻度で現われると推定 される. ウイルス量から考察すると, I 期は大部 分は $10^{9-13} \mathrm{copies} / \mathrm{m} l$ の高濃度の中和されていな いウイルスが存在し, II 期では $10^{5-6} \mathrm{copies} / \mathrm{m} l$ 以 下の中和されたウイルスが存在する. in vivo では I 期はウイルスの排出が見られ, 人から人への感 染が生じるが，II期では人から人への感染は見ら れない2). in vitroでは, I 期にある血清は感染宿 主である骨髄細胞中の CFU-e を傷害するが II 期 の血清は逆に CFU-e をパルボウイルスによる傷 害から保護する ${ }^{34)}$. 輸血に於いて，I期にある血 液は感染を惹起するがII期にある血液で感染が成 立するか否かは不明である。供血者スクリーニン グの為の短時間多検体処理に適しており, 且つ I 期及びII期の両方の時期をカバーする検查法が無
い現時点では，少なくともI 期にある感染性の高 い血液は供血者スクリーニングによって排除する のが望ましいと考えられる。

I 期の後半の時期より抗体が出現してくるが, ウイルスの中和抗体結合エピトープはウイルス キャプシッド蛋白の VP1特異領域及び VP1/VP2 共通領域にあることが知られており ${ }^{5)}$, 抗体の同 定には精製ウイルス又はVP1を含むリコンビナ ント抗原を使用して検査をすることが必要であ る.“編集者への手紙6)”の中で用いられている ELISA の抗原はVP2のみからなるリコンビナン 卜抗原を使用しており正しい評価を導く為には不 適切であろう. 又, もし全献血者を対象にしてス クリーニングを行うのであれば更なる検討や試薬 としての改良が必要となることは当然であろう が, 現時点では, 供血者スクリーニングの為の他 のいかなる実行可能な感染症検査に於いても, 全 ての PCR 陽性の検体をピックアップ出来るもの では無いということを認識しなければならない。

RHA 陽性率と PCR 陽性率の差について “編集 者への手紙”と筆者のデータに著しい差がみとめ られるとの指摘があったが，筆者は以前から用い られてきた Ouchterlony 法と新たに開発された RHA とを比較するために PCR で確認された検 体について陽性率を算出したもので population study ではないことを御承知願いたい. 又, “編集 者への手紙”では PCR 陽性検体の中で RHA 陽 性となるのはほほ $50 \%$ と記載し, 更に, RHAによ 
るスクリーニング陽性率が $0.008 \%$ PCR によ る陽性率が $0.8 \%$ と記載している.この矛盾は解決 されねばならない.

血漿分画製剤については，スクリーニングされ た血漿を材料として作られた製剤を用いたPUPs study 等によってその有効性の有無が明らかにさ れるであろう。

\section{文献}

1）佐藤博行：最近話題の感染症. ヒトパルボウイル ス B19とその感染症について. 日輸会誌，42(3)： 74-83, 1996.

2）岩崎环也：ヒトパルボウイルス研究の動向. Mdedical Briefs in Virus Infection, 7(5) : 1-4, 1994.

3) Mortimer, P.P., Humphries, R.K., Moore, J.G., Purcell, R.H. and Young, N.S.: A human parvovirus-like virus inhibits haemopoietic col- ony formation in vitro. Nature, $302: 426-429$, 1983.

4) Sato, H., Hirata, J., Furukawa, M., Kuroda, N., Shiraki, H., Maeda, Y. and Okochi, K. : Identification of the region including the epitope for a monoclonal antibody which can neutralize human parvovirus B19. J. Virol., 65(4) : 1667-1672, 1991.

5) Bansal, G.P., Hatfield, J.A., Dunn, F.E., Kramer, A.A.., Brady, F., Riggin, C.H., Collett, M.S., Yoshomoto, K.., Kajigaya, S. and Young, N.S. : Candidate recombinant vaccine for Human B19 Parvovirus. J. Infect. Dis., 167 : 1034-1043, 1993.

6) 佐藤進一郎, 加藤俊明, 関口定美: Receptormediated hemagglutination (RHA) によるヒ卜 パルボウイルス B19抗原スクリーニングの評価検 討. 日輸会誌, 42(5)：231-232, 1996. 